\title{
Analysis of Poultry Litter as a Fuel Source in Cogeneration
}

\author{
Nilesh C. Dhavane \\ PG Scholar, Department of Mechanical (Energy) \\ Engineering \\ Vidyapratishthan's Kamalnayan Bajaj Institute of \\ Technology, Baramati. M.S. India.
}

\author{
Dr. Parashuram R. Chitragar \\ Professor \\ Department of Mechanical Engineering \\ Vidyapratishthan's Kamalnayan Bajaj Institute of \\ Technology, Baramati. M.S. India.
}

\begin{abstract}
The aim of this research work is to utilize the available poultry litter as a substitutional fuel in cogeneration power plant in the sugar factory. In India, tons of poultry litter is damaging the fields due to uncontrolled disposal of poultry litter as fertilizer. It also contributes to the emission of greenhouse gases namely methane and carbon dioxide thus polluting the atmosphere. About 100 tons per day manure can be collected which can be used as fuel source at the location selected. With this amount of fuel available, energy can be generated in the cogeneration power plant. ost feasible of this work that can be implemented in cogeneration power plant in sugar factory.
\end{abstract}

Keywords:- Poultry litter, pollution, Fuel, Cogeneration, alternative Fuel Source.

\section{INTRODUCTION}

India is the world's third largest egg producer after China and the US and fifth largest poultry producer. At present, India produces about 6.25 to 8.0 million tons of poultry manure. With this amount of waste, India is now facing the problems of disposing it.

The nutritional value of fresh poultry manure deteriorates rapidly. Therefore, to prevent its rapid decomposition and to save its nutrient properties it is essential to process the manure immediately. Usually manure is stored for one month before disposal thus leads to loss of almost $40 \% \mathrm{~N}$. Thus, when it is dumped the effects are;

It is important to realize that poultry litter can be hazardous to environment and health of human and animals. Awareness of the potential hazards and problems related with poultry can greatly help in the understanding and developing of efficient poultry management practices.

\section{PROBLEM STATEMENT}

The poultry farm produces large amount of solid waste in which bedding material, saw dust, feed feathers, hatchery waste, excreta manure and this is called as poultry litter. The produced poultry litter facing the problem of disposing. Some of the amount of poultry litter is used as fertilizer in the farm for land spreading but there are many environmental issues like spreading diseases and pollute soil and groundwater. This poultry waste can serious environmental problem through odor and cause of reproduction of fly and rats. Another problem from the cogeneration power plant there is unavailability of bagasse in off season because of only approximately 180 days are the cropping day annually, in the remaining days the cogeneration power plant is stopped. This research work is based on to overcome the problems of the disposing poultry litter from the poultry farm and the cogeneration stopped due to unavailability of bagasse. These two problems can be solved by using the poultry litter as fuel source in the cogeneration power plant to produce the heat and power in the sugar factory as the power needed for the off season is comparatively less.

\section{OBJECTIVE}

The main aim of this research work is to eliminate the problem of disposing poultry litter and to analyze the poultry litter as fuel source in cogeneration plant. To do calculate moisture present in the poultry litter and the heating value of poultry litter on moisture content basis. To calculate boiler efficiency and evaporation ratio of the fuel poultry litter. To check the poultry litter biomass can be use in boiler $100 \%$ as a fuel as well as to check blending of the poultry litter with bagasse for generation of electricity.

The main objectives of this work is to reduce the loss of cogeneration plant in off season when there is unavailability of bagasse fuel by substitute poultry litter as fuel for the heat and power generation.

\section{ENERGY CALCULATIONS}

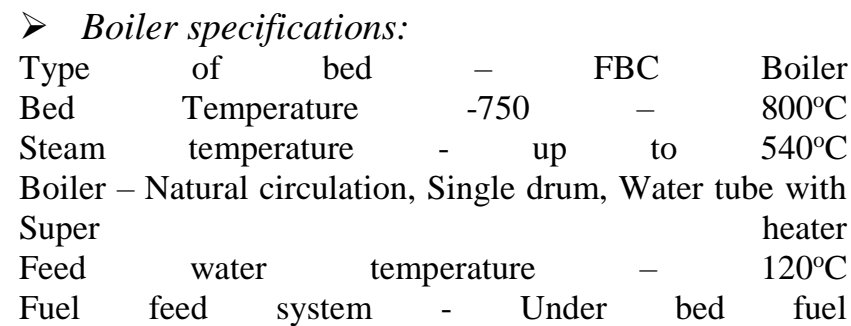

Fuel feed rate -3 to $5 \mathrm{~T} / \mathrm{hr}$. 
Steam Turbine Specifications:

Make:

Siemens

SST-

Output:

Inlet steam pressure: $\mathrm{P}_{\mathrm{i}}$ (st) $=65$ bar

Inlet steam temperature: $\mathrm{t}_{\mathrm{i}}(\mathrm{st})=480^{\circ} \mathrm{C}$

Exhaust Pressure $\mathrm{P}_{\mathrm{o}}(\mathrm{st})=15$ bar

From

steam

tables,

We have, for pressure $15 \mathrm{bar}$, temperature is $199^{\circ} \mathrm{C}$

Hence, $t_{0}(s t)=199^{\circ} \mathrm{C}$

$>$ Mass flow rate of steam turbine:

The steam turbine selected is Siemens SST- 060 and the mass Flow rate $m$ is given by,

Inlet pressure: $\mathrm{P}_{\mathrm{i}}(\mathrm{st})=65$ bar

Outlet pressure/back pressure: $\mathrm{P}_{\mathrm{o}}(\mathrm{st})=15 \mathrm{bar}$

Inlet temperature: $\mathrm{t}_{\mathrm{i}}(\mathrm{st})=480^{\circ} \mathrm{C}$

Outlet temperature: $\mathrm{t}_{\mathrm{o}}(\mathrm{st})=199^{\circ} \mathrm{C}$

Mass flow rate can be calculated by following formula:

$$
\dot{m}=\frac{P_{s t}}{h_{i(s t)}-h_{o(s t)}}
$$

$\mathrm{P}_{\mathrm{st}}$ is the power generated, which is $3 \mathrm{MW}$ by steam turbine.

$\mathrm{h}_{\mathrm{i}(\mathrm{st})}$ is the enthalpy at inlet of the turbine

$\mathrm{h}_{\mathrm{o}(\mathrm{st})}$ is the enthalpy at the outlet of the steam turbine.

From steam tables,

$\mathrm{H}_{\mathrm{i}(\mathrm{st})}=3369 \mathrm{Kg} / \mathrm{s}$

$\mathrm{H}_{\mathrm{i}(\mathrm{st})}=3369 \mathrm{Kg} / \mathrm{s}$

$\mathrm{m}=5.2 \mathrm{Kg} / \mathrm{s}=18.72 \mathrm{t} / \mathrm{hr}$

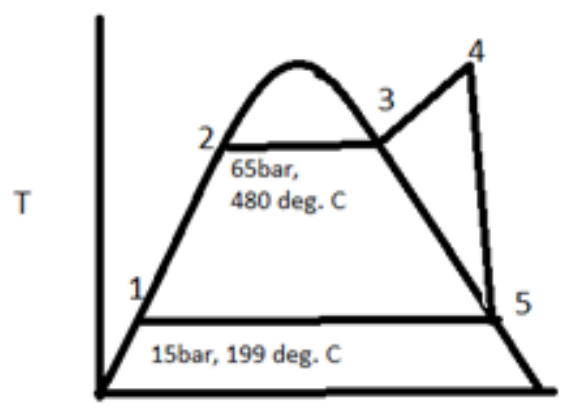

$\mathrm{S}$

Fig 1:- FBC Temperature - Enthalpy diagram

\section{$>$ Superheater}

Super heaters are one of the most important accessories to improve thermal efficiency of boiler. It converts wet saturated steam in dry steam.

The superheater heat load is written as:

$$
\dot{Q}_{s h}=\left[\dot{m}_{s t}\left(h_{o}-h_{s_{i}}\right)\right]
$$

The steam enthalpy at the outlet of the superheater is determined by knowing the pressure and temperature of the steam at the outlet of the superheater. The pressure at the inlet of the superheater can be calculated by adding the pressure drop in the superheater to the designed outlet pressure:

$$
p_{s h(i)}=p_{s h(o)}+\Delta P_{s h}
$$

During the initial thermal design, when the type of superheater has not been decided, the pressure drop $\Delta \mathrm{P}_{\text {sh }}$ is estimated as $10 \%$ of the steam pressure at the outlet of superheater or obtained from experience or from the manufacturer of the superheater. Steam at the inlet of the superheater is saturated at the pressure $p_{s h(i)}$. Therefore; its temperature is the saturation temperature corresponding to this pressure.

To calculate superheater heat load; (Saturated steam in drum)

Pressure at inlet of superheater $=\mathrm{p}_{\mathrm{sh}(\mathrm{i})}=71.5 \mathrm{bar}$ Temperature at inlet of superheater $=t_{\operatorname{sh}(\mathrm{i})}=287^{\circ} \mathrm{C}$ Enthalpy at inlet of superheater $=h_{\text {sh(i) }}=2771 \mathrm{KJ} / \mathrm{kg}$ $\mathrm{Q}_{\text {sh }}=3109.6 \mathrm{~kW}$

\section{$>$ Evaporator:}

The pressure at the inlet and outlet of the evaporator can be taken as the drum pressure plus the hydrostatic head and the inlet pressure of the superheater plus the drop across the drum internals, respectively. Temperature at the outlet of the evaporator can be assumed to be the saturated steam temperature at the pressure of $p_{s h(i)}$ plus the drum internal drop. The inlet temperature in the evaporator is expected to be slightly lower due to the mixing of cooler water from the economizer with the saturated water. For rough estimation, it can be taken as $15^{\circ} \mathrm{C}$ below the saturation temperature $\mathrm{t}_{\mathrm{w}(\mathrm{sat})}$ at drum pressure:

(Saturated water in drum) Pressure of drum $=\mathrm{p}_{\mathrm{sh}(\mathrm{i})}=71.5$ bar Temperature of drum $=t_{\text {drum }}=t_{\text {sh(i) }}=287{ }^{\circ} \mathrm{C}$ Enthalpy of drum water $=h_{w(s a t)}=1273 \mathrm{KJ} / \mathrm{kg}$

(Water at outlet of economizer) Pressure at outlet of economizer $=p_{\text {eco(o) }}=71.5$ bar Temperature at outlet of economizer $=t_{\text {eco(o) }}=272{ }^{\circ} \mathrm{C}$ Enthalpy at outlet of economizer $=\mathrm{h}_{\mathrm{eco}(\mathrm{o})}=1195 \mathrm{KJ} / \mathrm{kg}$

To calculate evaporator heat load;

$$
\begin{gathered}
\dot{Q}_{\text {evap }}=\left[\dot{m}_{s t}\left(h_{s h(i)}-h_{\text {eco }(o)}\right)\right] \\
\mathrm{Q}_{\text {evp }}=8195.2 \mathrm{~kW}
\end{gathered}
$$

$>$ Economizer:

Economizer is a heat exchanger that uses waste heat from boiler exhaust to preheat the feed water into the boiler. of fuel.

This improves the boiler efficiency and reduces costs 
Pressure at the inlet of the economizer can be calculated by adding economizer pressure drop, $\Delta \mathrm{P}_{\mathrm{eco}}$ to its outlet pressure:

$$
p_{e c o(i)}=p_{e c o(o)}+\Delta P_{e c o}
$$

The pressure at the economizer outlet can be assumed to be the drum pressure plus the hydrostatic head above its inlet and the friction in piping. The temperature at the economizer inlet is the same as the feed water temperature, and the outlet temperature can be assumed as the temperature at the inlet of the evaporator.

Feed water properties, Pressure at inlet of economizer $=p_{\text {eco(i) }}=78.65$ bar Temperature at inlet of economizer $=t_{\text {eco }(\mathrm{i})}=30^{\circ} \mathrm{C}$ Enthalpy at inlet of economizer $=\mathrm{h}_{\mathrm{eco}(\mathrm{i})}=125 \mathrm{KJ} / \mathrm{kg}$

The economizer heat load is written as:

$$
\begin{gathered}
\dot{Q}_{e c o}=\left[\dot{m}_{s t}\left(h_{e c o(o)}-h_{e c o(i)}\right)\right] \\
Q_{\text {eco }}=5559.84 \mathrm{~kW}
\end{gathered}
$$

The total heat load of the boiler is found by adding above terms:

$$
\dot{Q}_{\text {steam }}=\dot{Q}_{\text {sh }}+\dot{Q}_{\text {evap }}+\dot{Q}_{\text {eco }}
$$

$$
\mathrm{Q}_{\text {steam }}=16864.64 \mathrm{~kW}
$$

$$
\begin{aligned}
& >\text { To calculate efficiency of turbine: } \\
& \mathrm{T}(\mathrm{i})=480^{\circ} \mathrm{C} \\
& \mathrm{P}(\mathrm{i})=65 \mathrm{bar}
\end{aligned}
$$

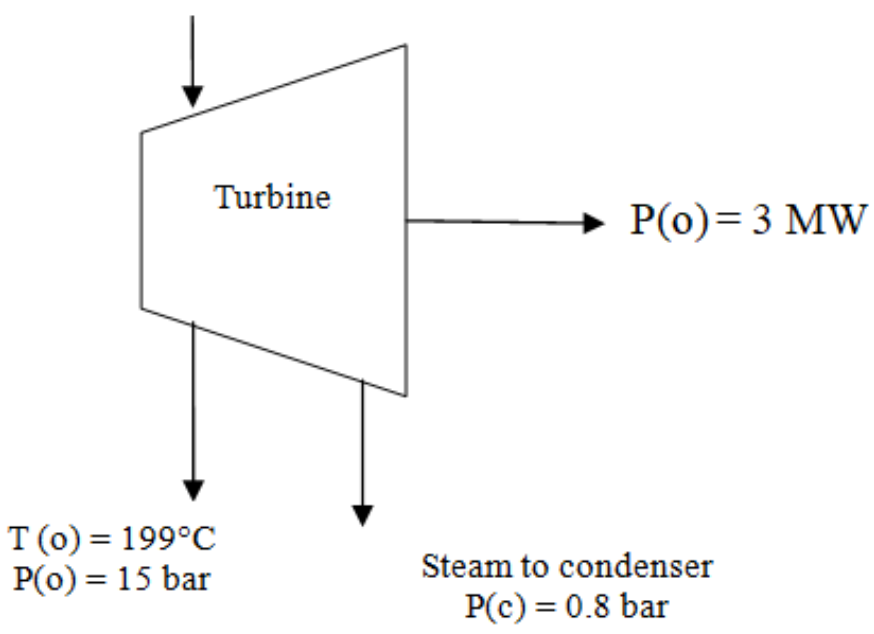

Fig 2:- Turbine inlet and outlet parameters

\section{Input:}

Enthalpy of steam $\left(h_{\mathrm{s}}\right)=$ [mass flow rate of steam] X [Enthalpy of steam at 65 bar $\& 480^{\circ} \mathrm{C}$ temperature (from steam table)] $\left(\mathrm{h}_{\mathrm{s}}\right)=63067680 \mathrm{kcal} / \mathrm{hr}$.

\section{Output:}

- Electrical Energy $=[$ Power output X 860] / [Efficiency of Steam Turbine]
- Enthalpy of steam to process $=$ [mass flow rate of steam] X [Enthalpy of steam at 15 bar \& $199^{\circ} \mathrm{C}$ temperature (from steam table)]

- $\quad$ Enthalpy of steam to condensate $=$ mass flow rate of steam X Enthalpy at 0.8 bar

Since; Energy Input = Energy Output, the only variable unknown is $\mathrm{x}$ i.e. quantity of steam required which can be calculated using:

$$
\begin{aligned}
& a)=b(i)+b(i i)+b(i i i) \\
& \eta=75.60 \%
\end{aligned}
$$

\section{The quantity of fuel can be determined as:}

Gross calorific value (GCV) of fuel is $2800 \mathrm{kcal} / \mathrm{hr}$.

$$
\text { Fuel quantity }=\frac{\text { Enthalpy of steam at inlet to turbine }}{\text { Boiler efficiency } X \text { GCV of fuel }}
$$

\section{Fuel quantity $=138.61$ tons/day}

From calculations it can be observed that fuel required is totally dependent on power output and steam mass flow rate to turbine. Moreover, to be noted power output and steam mass flow rate are never constant. Therefore, actual fuel quantity required is estimated only for a certain period. Mostly, inventory of fuel is maintained for at least a period of 7 days. Furthermore, peak load time is also considered for fuel quantity required. The system can perform at low efficiency during average or low load period, if it is designed to give output only at peak loads.

Also, power required for various equipment's like; pumps, ID and FD fans, dust collecting system, water treatment plant, cooling towers, material and ash handling systems should be considered while designing. As a thumb rule, power consumed by this equipment's (auxiliary power) is considered to be $12-15 \%$ of total power generated.

\section{RESULTS AND DISCUSSION}

The poultry litter production by bird from poultry farm is $0.094 \mathrm{~kg} /$ day. For $3 \mathrm{MW}$ Power generation poultry litter fuel required is 138.61 tons/day. It requires 14.74 lakh chicken birds nearer the area that can be reduce the transportation cost of the fuel. By using poultry litter as fuel in cogeneration for the remaining 180 days off season of the sugar factory can be generation of power with minimum fuel cost.

\section{Environmental Favorable Factors:}

- Reduction of emissions -

Methane has 25 times greater impact on environment than $\mathrm{CO}_{2}$. As energy is generated from poultry litter instead of dumping in open fields hence, methane emissions are reduced. 
$\mathrm{CO}_{2}$ emissions are reduced. For the location selected only 100 ton/day manure is used which saved almost 14,000 ton $\mathrm{CO}_{2}$ /years emissions. On the other hand in India almost 80 million tons of litter per day is generated. Making use of it to generated electricity could save huge $\mathrm{CO}_{2}$ emissions. $\mathrm{SO}_{2}$, SOx \& NOx emissions are reduced through use of renewable resource for energy generation.

\section{- Improved soil and water quality -}

The project delivers a high quality potash and phosphate rich organic fertilizer i.e. ash from combustion or slurry from biogas plant. This fertilizer could enrich the quality of soil as compared to conventional practice. Contamination of water is reduced as there is no poultry litter dumping on open field.

\section{- Preservation of natural resources -}

Dependence on fossil fuel is reduced which increases the energy capacity of country and stimulates the growth of the renewable market. Promote local enterprises to use discarded litter rather than leaving it to decay.

\section{- $\quad$ Proper waste management -}

There is reduction in odor problem, formation of flies and decreased diseases. Optimizes the use of renewable resources therefore it avoids new uncontrolled waste disposal sites.

\section{CONCLUSION}

This research work has assessed the environmental impacts of generating electricity from poultry litter in a small-scale cogeneration plant in sugar factory. Use of poultry waste to energy has significant scope and potential. Energy can be recovered by generating electricity and the by product can be used as fertilizer. Hence, initiatives to generate electricity should be started by the government as the poultry waste production is around 8 million tons per day in India. The results show that using poultry litter as an alternative fuel to generate electricity in a small-scale cogeneration power plant in the sugar factory is an environmentally viable option. However, the successful application of this technology will depend on the future reduction in loss of cogeneration plant in off season.

By using poultry litter as fuel source in cogeneration in to the sugar factory can the overcome of many problems facing like disposing of poultry waste, reduces land pollution, reduces emission and the loss of cogeneration plant in sugar factories in off season.

\section{REFERENCES}

[1]. Dr.Saubhagya Muduli, Dr.Abhijit Champati, Dr.Haresh K. Popalghat, Dr. Poonam Patel, Dr. K. R. Sneha; "Poultry Waste Management An approach for sustainable development." International Research ISSN - 2456-0421, Volume - 4, Page No. 08-14 Jan.2019

[2]. Purnima Singh, Tanmay Mondal, Rachana Sharma, N. Mahalakshmi, Mokshta Gupta, "Poultry Waste
Management." International Journal of Current microbiology and Applied Sciences. ISSN - 23197706, Volume - 7, Nov 2018

[3]. Harish K Jeswani, Andrew Whiting, Alastair Martin, Adisa Azapagic, "Environmental Impact of Poultry Litter Gasification for Power Generation." International conference on Sustainable Energy and Resource use in Food Chain, ICSEF, oct. 2018.

[4]. M. Bolhar, F. Gartner, I Tschanun, S. Kaiser, "Combustion of Poultry Litter in Bubbling Fluidized Beds." Austrian Energy and Environment. June 2019

[5]. Barry Bowen, Declan Lynch, Deirdre Lynch, Anne Marie Henihan, James J. Leahy, Kevin Mc Donnell; "Fluidized Bed combustion and Energy Recovery From Poultry Litter." Sustainability July 2010.

[6]. Dayanand B. S., Sreepathi L. K., "Design and analysis of Fluidized Bed Gasifier for Chicken Litter along with Agro Wastes." International Research Journal of Environment Science. Vol. 1(3), Oct 2012.

[7]. M. O. Oliveria, R. Somariva, O. H. Ando Junior, J. M. Neto, A. S. Bretas, O. E. Perrone., " Biomass Electricity Generation Using Industry Poultry waste." European Association for the Development of R.E. Environment and power Quality. March 2012.

[8]. K. Naresh, S. N. Ravi Teja, K Datta, Sri Harsha, "Poultry Litter as Renewable Energy Resource Using SOFC Technology." International Electrical Engineering Journal (IEEJ), Vol. 4 (2013), P.P. 914 917.

[9]. ASM Mominul Hasan, Md. Fayyaz Khan, Raquibul Mostafa, Azizul Kaium., "Feasibility Study on Electricity Generation from Poultry Litter Based Biogas in Bangladesh."

[10]. J. P. Chastain, A Coloma - del valle,K.P. moore., "Using Broiler Litter As an Energy source: Energy content and ash composition ." ASABE - March 2012.

[11]. Rajendra Singh, Amrit B. Karki, Jagan Nath Shrestha., "Production of Biogas from poultry Waste." International Journal of Renewable Energy, Vol. 3, No. 1, January 2008.

[12]. Philip Metcalfe "Large Scale Combustion of Animal manure in the United Kingdom.

[13]. J. J. Ramirez, J. D. Martine Z, S.L. Petro, "Basic Design of A Fluidized Bed Gasifier for Rice Husk on A Pilot Scale." Latin American applied Research 2007.

[14]. Rumana Rashid, ABM Mahabubul Malik, Md Sayem Khan, "Biological Treatment of organic Waste for Poultry Farm in hot climate." International Journal of Sustainable Water and Environmental Systems.Vol.1 No. 1, 2010. 